\section{Mr. F. F. Renwick}

I Jus' missed Renwick at the City of London School. $\mathrm{He}$ entered at about the same time as I left and had thus the good fortune to come into contact with Owen Glynne Jones, whose chemical knowledge must have proved a valuable stimulus to Renwick's interest in chemistry. After leaving, he went to the Science Section of the City and Guilds Institute at South Kensington, where he had the privilege of being under Armstrong. He was also in close contact there with Pope, with whom he remained friends for the rest of his life, and he became well acquainted with Philip, an acquaintanceship which helped to further his social development.

Renwiek joined the staff of Ilford, Ltd., in 1898, but I had no contact with him until 1910, when I also joined the firm. I remember well those early days when three chemists were for some years the whole of the scientific staff of Ilford, Ltd., those three chemists being Renwick, Store, and myself. I also remember the interminable discussions, not on chemical matters but on politics and above all on religion. One of us was a broad-minded Church of England man, the second a broad-minded Unitarian and the third an Agnostic. Never did those three agree and never did they come to any conclusion, each termination of the argument leaving each of the men with his own point of view intact.

The work in those days consisted of emulsion experiments and constant work on Ilford "pinpoints". This necessitated the use of a high-powered microscope and an everlasting endeavour to recog. nize the minute particles, chiefly in the gelatine, which were the cause of the particular trouble under review. It was not long, however, before this work gave way to problems which were more intricate and harder of solution. Such problems included the behaviour of translution densities when in optical contact with one another, and I recall the months of argument which went on before the final paper on luminosity by Renwick, Store and Channon was published by the Royal Society.

Renwick's scientific work dealt with at least three recurrent themes. The first of these, photographic sensitometry and tone reproduction, with its funda. mental problem of the significance and the measurement of photographic densities, developed stage by stage throughout his working life. Arising from that work he made, with W. B. Ferguson and D. E. Benson, the "F.R.B. Densitometer" which was to serve for many years as a standard. Armed with this instrument, he turned his attention to the broader question of photographic tone reproduction. This led him to consider the desirable sensitometric properties of photographic papers. Secondly, he made contributions to the theory of the photographic latent image. In 1920 he advanced the view that the action of light is to coagulate particles of silver present in the sensitive grains of an emulsion, so as to form a centre large enough to act as a nucleus for development. His third quest was for a photographic material, incorporating fluorescent substances, which would have a greatly enhanced sensitivity to X-rays. Using complexes of lead sulphate and barium sulphate, very efficient and relatively cheap $\mathrm{X}$-ray intensifying media were produced under the names "Kryptosereen" paper and "Brytex" intensifying leaves.

In 1922 Renwick left for the United States to take charge of the Dupont Film Factory and remained there until 1925, when he came back to England because he felt that the education of his children should take place in their own eountry. When he returned to Ilford, Ltd., he came as a director.

I have vivid memories of long walks prior to his stay in America. After his return he was too busy to indulge in much walking; had he been able to continue I think his health would have been the better for the exercise.

Naturally, as Renwick's responsibilities increased and the Royal Photographic Society took up more and more of his spare time, not to mention the demands of his growing family, we saw less of one another on the social side. In the latter (war) years of his life he also shouldered the added responsibilities of A.R.P. duties.

Those of us who knew him well feel that we have lost a master of photographic science who can ill be spared from the excellent work he was doing, and know that we shall not be likely to see his equal again.

O. BLOCH.

\section{Mr. R. Borlase Matthews}

WITH regret we have to record the passing under tragic circumstances of another pioneer in electrical engineering. Following a bathing accident in which his eighteen-year-old son David was drowned, $\mathrm{Mr}$. Richard Borlase Matthews, who had gone to the boy's rescue, died on August 20 from the effects of shock and exhaustion.

Born in 1876, Mr. Matthews was educated at the Grammar School and Technical College, Swansea, at the Royal School of Mines, and at the Royal College of Science and Central Technical College, London. After serving his apprenticeship with the Milbrook Iron and Steel Company, Swansea, he became assistant engineer with Robert Blackwell and Co., afterwards going to the United States, where he joined the National Electric Co. at Milwaukee, then the General Electric Co. at Schenectady and later the Edison Electric Light and Power Company at Amsterdam. Returning to England, he practised as a consulting engineer in 1906, and specialized in high-voltage electric transmission, the design of power stations, and the applications of electricity to heating and domestic purposes. In 1908 he took up aeronautical work and during the War of 1914-18 he was in the Applied Design (Liaison) Department of the Air Ministry. Afterwards, on his 600-acre all-electric farm at Great Felcourt, East Grinstead, Sussex, he carried out extensive experiments on the application of electricity to agriculture, and published a number of papers on the subject. In collaboration with Dr. Elkstrom, Mr. Matthews initiated a scheme for electricity supply in the areas now served by the MidLincolnshire Electric Supply Co. and in 1930 he was appointed a director of the Company.

Mr. Matthews was a Whitworth exhibitioner, a mem. ber of the Institution of Electrical Engineers and an associate member of the Institution of Civil Engineers, as well as a fellow of the Royal Aeronautical Society.

WE regret to announce the following deaths:

Dr. G. E. Pilgrim, F.R.S., formerly superintendent of the Geological Survey of India, on September 15.

Dr. F. J. W. Whipple, formerly superintendent of the Kew Observatory, on September 25, aged sixty. seven. 